\title{
PENINGKATAN HASIL BELAJAR SISWA DENGAN MENGGUNAKAN MODEL PEMBELAJARAN STUDENT FACILITATOR AND EXPLAINING PADA TEMA DAERAH TEMPAT TINGGALKU DI KELAS IV SD SWASTA BUDI MURNI 2 TAHUN PEMBELAJARAN2018/2019
}

\author{
MARTINUS DAKHI \\ (PGSD FKIP UNIVERSITAS KATOLIK SANTO THOMAS)
}

\begin{abstract}
Discuss about the area where I live, based on the results of observations done in class IV SD Swasta Budi Murni 2 it was found some problems, they were: has not implement the varian model thus the learning is concerned on that teacher that make students fat unmotivated to study got bored. The problem to the result of students learning. Thus it needs to conduct a classroom action research. Classroom action research consists of four steps namely planning, implementation, observation and reflection which conducted into two cycle with one meeting in every cycle. The subject of this research in students of SD Swasta Budi Murni 2 Class IV in the academic year 2018/2019 with the number of the students are 48 . The technique of collecting date use lest and observation.

The results of the observation skills of teachers cycle I gained an average percentage score of $70.91 \%$ with good criteria. Cycle II obtained the average percentage score $86 \%$ with good criteria as well. The data showed an increase in the skills of teachers. The results of the observation activities of students cycle I gained an average of 68 with sufficient criteria. In cycle II, increased with the acquisition of a score of 88 with good criteria. Thoroughly of classical results on prates by $29.17 \%$ with an average of 67.5 class, on cycle I Thoroughly of classical learning of $47.91 \%$ with an average 73.43 class, and in cycle II Thoroughly of classical learning of $95.83 \%$ with an average of 95.45 class. The data showed an increase in student learning results.
\end{abstract}

Keywords: The Result Learning Students, The Theme of The Area Where I Live, and Learning Model Student Facilitator And Explaining

\section{PENDAHULUAN}

\section{Latar Belakang Masalah}

Pendidikan merupakan hal yang tidak dapat dipisahkan dari kedudukan manusia karena pendidikan adalah salah satu proses pembentukan sikap, kepribadian dan keterampilan manusia dalam menghadapi cita-cita dimasa depan. Dengan proses sikap kepribadian dan keterampilan akan memberikan hasil yang bervariasi sesuai dengan kemampuan dan perkembangan manusia itu sendiri. Pendidikan sebagai perubahan yang diinginkan dan diusahakan dalam proses pendidikan, baik pada tataran relasi dengan alam sekitar. Pendidikan memfokuskan perubahan tingkah laku manusia yang konotasinya pada pendidikan etika.Disamping itu, pendidikan menekankan aspek produktivitas dan kreativitas manusia sehingga mereka bisa berperan serta berprofesi dalam kehidupan bermasyarakat. Semakin tinggi pendidikan yang akan dicapai seseorang maka akan 
semakin baik kehidupannya. Dalam dunia pendidikan harus ada proses belajar mengajar dilakukan, supaya adanya interaksi guru dengan siswa.

Seperti yang kita ketahui bahwasannya pendidikan pada saat ini berorientasi pada proses dan hasil pembelajaran. Keberhasilan siswa bukan hanya dilihat dari hasil belajarnya saja melainkan dari keaktifannya selama proses pembelajaran berlangsung dan juga mempengaruhi oleh lingkungan dimana dia berada. Sering kita jumpai ketika dalam proses belajar mengajar, siswa masih sering dianggap sulit bahkan dianggap membosankan dalam belajar. Hal tersebut terjadi karena ada beberapa hal yang belum diketahui oleh pendidik.

Metode yang selalu digunakan dalam proses pembelajaran yaitu metode ceramah dan diskusi sehingga membuat siswa merasa bosan dan mengantuk. Sementara itu kurangnya minat siswa dalam belajar. Suasana kelas yang ramai lebih menarik perhatian siswa untuk bercanda bersama teman-temannya dan menimbulkan keributan sehingga membuat siswa sulit berkonsentrasi dalam mengikuti pelajaran yang disampaikan guru. Masalah bererikutnya, siswa mengalami kesulitan untuk mengungkapkan kembali isi dari materi yang mereka pelajari. Banyak siswa yang belum mampu menjelaskan kembali di depan kelas materi pelajaran yang telah dijelaskan oleh guru, berdasarkan pemahamannya. Sehingga kurangnya keaktifan siswa dalam proses pembelajaran.

Berdasarkan pengalaman peneliti pada saat Praktek Pengalaman Lapangan (PPL) di sekolah praktikan banyak dijumpai siswa yang masih memiliki kemampuan belajarnya rendah. Hal ini juga sejalan pada saat proses pembelajaran di kelas, dimana siswa kebanyakan kurang konsentrasi sehingga materi pembelajaran yang disampaikan sulit untuk diingat oleh siswa. Selain itu pada saat guru memberikan pengajaran kepada siswa, siswa kurang memahami isi pesan yang disampaikan oleh guru dan ketika ditanya kembali oleh guru terkait materi yang baru saja disampaikan kebanyakan siswa tidak mengingat kembali materi tersebut.

Pernyataan peneliti tersebut juga diperkuat dengan hasil wawancara dengan guru kelas IV SD Swasta Budi Murni 2 yang bernama Ibu Lestrida Sihombing, S.Pd. Hasil wawancara yang diperoleh, guru tersebut mengatakan: "Pada saat proses pembelajaran khususnya dalam hal mengikuti pelajaran, hasil belajar siswa masih berada pada kategori rendah terbukti dari hasil belajar mengenai Tema Daerah Tempat Tinggalku dan sub tema bangga terhadap daerah tempat tinggalku Tahun Pembelajaran 2017/2018”. Adapun hasil nilai ujian harian siswa tema daerah tempat tinggalku dapat dilihat pada tabel di bawah ini. 


\section{Hasil Nilai Ujian Harian Siwa Kelas IV SD Swasta Budi Murni 2 Tahun} Pembelajaran 2017/2018

\begin{tabular}{|c|l|c|c|c|c|c|}
\hline T.P & Mata Pelajaran & KKM & $\begin{array}{l}\text { Tidak Memenuhi } \\
\text { KKM }\end{array}$ & Keterangan & $\begin{array}{c}\text { Memenuhi } \\
\text { KKM }\end{array}$ & Keterangan \\
\hline \multirow{2}{*}{$2017 /$} & PKN & 75 & $\begin{array}{l}32 \\
(66,67 \%)\end{array}$ & $\begin{array}{c}\text { Tidak } \\
\text { Tuntas }\end{array}$ & $\begin{array}{l}16 \text { orang } \\
(33,33 \%)\end{array}$ & Tuntas \\
\cline { 2 - 8 } & IPS & 75 & $\begin{array}{l}34 \\
(70,83 \%)\end{array}$ & $\begin{array}{c}\text { Tidak } \\
\text { Tuntas }\end{array}$ & $\begin{array}{l}14 \text { orang } \\
(29,16 \%)\end{array}$ & Tuntas \\
\cline { 2 - 8 } & BAHASA & 75 & $\begin{array}{l}31 \\
(64,58 \%)\end{array}$ & $\begin{array}{c}\text { Tidak } \\
\text { Tuntas }\end{array}$ & $\begin{array}{l}17 \text { orang } \\
(35,41 \%)\end{array}$ & Tuntas \\
\hline
\end{tabular}

Dari table di atas dapat diketahui bahwa hasil belajar siswa masih berada pada kategori rendah. Terbukti dari hasil belajar mengenai TemaDaerah Tempat Tinggalku dan sub tema bangga terhadap daerah tempat tinggalku belum mencapai KKM yang telah ditentukan oleh pihak sekolah. Pada mata pelajaran PKN dari 48 orang siswa, hanya 16 orang siswa atau $(33,33 \%)$ yang memperoleh nilai diatas KKM dan 32 siswa atau 66,67\%, pada mata pelajaran IPS dari 48 siswa yang mencapai nilai KKM dalah 14 orang siswa atau $(29,16 \%)$ dan yang tidak mencapai nilai KKM adalah 34 orang siswa atau $(70,83 \%)$, pada mata pelajaran BAHASA INDONESIA dari 48 orang siswa yang mencapai nilai KKM adalah 17 orang siswa atau $(35,41 \%)$ dan yang tidak mencapai nilai KKM adalah 31 orang siswa atau $(64,58 \%)$.Hal tersebut terjadi karena siswa kurang memiliki minat dalam belajar. Untuk mengatasi masalah yang terjadi maka guru perlu memperhatikan pemilihan model pembelajaran.

Oleh karena itu, pelaksanaan pengajaran seorang guru sangat memerlukan model dalam proses belajar mengajar di sekolah sebagai penunjang untuk mencapai tujuan pembelajaran yang di harapkan. Model pembelajaran dapat diartikan sebagai cara maupun pola yang mempunyai tujuan menyajikan pesan kepada siswa agar dapat dipahami, dengan memperhatikan kemampuan peserta didik, materi dan kelas yang digunakan sebagai penerapan model pembelajaran tersebut. Model pembelajaran ini akan relevan apabila siswa secara aktif ikut serta dalam merancang materi pembelajaran yang akan dijelaskan. Model pembelajaran student facilitator and explaining dapat memberikan kesempatan pada siswa untuk menjelaskan kepada rekannya, dan mendorong berkembangnya potensi berpikir kritis peserta didik secara optimal.

Dalam hal ini Kurniasih dan Sani (2016: 79) menyatakan bahwa"model pembelajaran student facilitator and explaining ini merupakan model pembelajaran yang 
melatih siswa untuk dapat mempresentasikan ide atau gagasan mereka pada temantemanya. Model pembelajaran ini akan relefan apa bila siswa secara aktif ikut serta dalam merancang materi pembelajaran yang akan di presentasikan". Penelitian yang dilaksanakan oleh pada tahun (2015) dengan judul penelitian "Penerapan Model pembelajaran Student Facilitator and Explaining untuk meningkatkan hasil belajar PKN siswa kelas IV SDN 5 Tallunglipu Kabupaten Toraja Utara', Pada jurnal KIP, IV (2) julioktober 2015, 879-886 menggungkapkan bahwa model pembelajaran Student Facilitator and Explaining dapat meningkatkan hasil tes siswa dari tahap siklus I ketuntasan belajar siswa $64,71 \%$ dan meningkat pada tahap siklus II dengan ketuntasan belajar mencapai 91,42\%. Dari latar belakang tersebut, untuk menjawab permasalahan yang ada maka peneliti perlu meneliti tentang "Peningkatan Hasil Belajar Siswa dengan Menggunakan Model PembelajaranStudent Facilitator and Explaining pada Tema Daerah Tempat Tinggalku Di Kelas IV SD Swasta Budi Murni 2 Tahun Pembelajaran 2018/2019',

\section{Identifikasi Masalah}

Berdasarkan latar belakang masalah di atas, maka dapat diidentifikasi masalahmasalah yang relevan dengan penelitian ini. Terdapat tujuh hal yang menjadi identifikasi masalah.

1. Hasil belajar siswa masih rendah

2. Metode yang selalu digunakan dalam proses pembelajaran yaitu metode ceramah dan diskusi sehingga membuat siswa merasa bosan dan mengantuk

3. Siswa kesulitan untuk mengungkapkan kembali isi dari materi yang mereka pelajari.

4. Kurangnya keaktifan siswa dalam proses pembelajaran.

5. Rendahnya kemampuan belajar siswa.

6. Suasana kelas yang ramai lebih menarik perhatian siswa untuk bercanda bersama teman-temannya dan menimbulkan keributan sehingga membuat siswa sulit berkonsentrasi dalam mengikuti pelajaran yang disampaikan guru.

7. Siswa kurang memahami isi pesan yang disampaikan oleh guru dan ketika ditanya kembali oleh guru terkait materi yang baru saja disampaikan kebanyakan siswa tidak mengingat kembali materi tersebut.

8. Kurangnya minat siswa dalam belajar karna di pengaruhi oleh teman-temanya

\section{Pembatasan Masalah}

Berdasarkan uraian pada latar belakang dan identifikasi masalah di atas, perlu dilakukan pembatasan masalah agar penelitian ini lebih terarah dan terfokus pada masalah 
yang akan diteliti. Oleh karena itu, masalah penelitian ini dibatasi pada: "peningkatan hasil belajar siswa dengan menggunakan model pembelajaran student facilitator and explaining pada tema daerah tempat tinggalku dengan sub tema bangga terhadap daerah tempat tinggalku pembelajaran 4 di Kelas IV SD Swasta Budi Murni 2 Medan Tahun Pembelajaran 2018/2019."

\section{Perumusan Masalah}

Berdasarkan rumusan masalah diatas, yang menjadi tujuan penelitian ini adalah:

1. Apakah terdapat perbedaan hasil belajar melalui penerapan model pembelajaranstudent facilitator and explainingpada tema daerah tempat tinggalku dengan sub tema bangga terhadap daerah tempat tinggalku pembelajaran 4 di kelas IVSD Swasta Budi Murni 2 Tahun Pembelajaran2018/2019?

2. Bagaimanakahhasil belajar siswa dengan penerepan model pembelajaran student facilitator and explaining pada tema daerah tempat tinggalku dan sub tema bangga terhadap daerah tempat tinggalku pembelajaran 4 di kelas IV SD Swasta Budi Murni 2 Tahun Pembelajaran 2018/2019?

\section{Tujuan Penelitian}

Adapun tujuan penelitian ini adalah:

1. Untuk mengetahui hasil belajar siswa dengan penerapan model pembelajaranstudent facilitator and explainingpada tema daerah tempat tinggalku dengan sub tema bangga terhadap daerah tempat tinggalku pembelajaran 4 di kelas IV SD Swasta Budi Murni 2 Tahun Pembelajaran 2018/ 2019.

2. Untuk mengetahui pelaksanaan pembelajaran daerah tempat tinggalku dengan sub tema bangga terhadap daerah tempat tinggalku pembelajaran 4 setelah menggunakan model pembelajaran student facilitator and explainingdi kelas IV SD Swasta Budi Murni 2 Tahun Pembelajaran 2018/ 2019.

\section{Manfaat Penelitian}

Hasil penelitian ini diharapkan dapat memberikan manfaat secara teoretis dan praktis.Kedua hal tersebut dapat diuraikan di bawah ini.

1. Manfaat Teoretis

Penelitian ini diharapkan dapat memberikan masukan yang sifatnya membangun bagi teori pada tema daerah tempat tinggalku.Sebab dengan pengunaan model pembelajaran yang lebih variatif dapat menciptakan suasana belajar yang kondisif dan menyenangkan. 
2. Manfaat Praktis

a. Manfaat untuk guru

1) Mengetahui prosedur pembelajaran pada tema daerah tempat tinggalku dengan menggunakan model pembelajaran student facilitator and explaining.

2) Menggunakan model pengajaran yang lebih bervariasi menarik, kreatif dan efektif.

b. Manfaat untuk siswa

1) Mendapat pengalaman baru pada tema daerah tempat tinggalku dengan menggunakan model pembelajaran student facilitator and explaining.

2) Dalam penggunaan model student facilitator and explaining dapat mebantu proses pemahaman, pengetahuan dan menciptakan hasil belajar yang baik.

3. Manfaat bagi sekolah: Sebagai salah satu evaluasi betapa penting penggunaan model dalam proses pengajaran secara bervariasi.

4. Manfaat untuk peneliti: Dapat memperluas ilmu pengetahuan peneliti mengenai model pembelajaran student facilitator and explaining untuk dapat meningkatkan hasil belajar peserta didik.

\section{METODOLOGI PENELITIAN}

\section{Pendekatan dan Metode Penelitian}

Dalam proses penelitian ini peneliti menggunakan metode campuran yang dikombinasikan dari dua macam pendekatan yaitu pendekatan kuantitatif dan kualitatif. Pendekatan kualitatif dan kuantitatif masing-masing memiliki keterbatasan, oleh sebab itu, ada kecenderungan untuk menggabungkan pendekatan kuantitatif dan pendekatan kualitatif yang kemudian dikenal dengan pendekatan campuran.

Dalam hal ini Arikunto (2017: 1-2) menyatakan bahwa“Penelitian Tindakan Kelas adalah penelitian yang memaparkan terjadinya sebab akibat dari perlakuan, dan memaparkan seluruh proses sejak awal pemberian perlakuan sampai dengan dampak dari perlakuan tersebut. Dengan demikian, dapat dikatakan bahwa penelitian tidakan kelas atau PTK adalah jenis penelitian yang memaparkan baik proses maupun hasil, yang melakukan PTK di kelasnya untuk meningkatkan kualitas pembelajarannya'. selanjutnya Slahudin (2015: 24) menyatakan bahwa "penelitian tindakan kelas adalah penelitian praktis untuk memperbaiki pembelajaran didalam keslas". Pemilihan metode ini didasari upaya sebagi peningkatan hasil belajar yang berlangsung dalam tahapan siklus. Penelitian ini dilakukan bermula dari perencanaan, pelaksanaan, pengamatan, dan refleksi. Tujuan penilitian 
tindakan kelas ini adalah meningkatkan respon siswa dengan menggunakan model pembelajaran student facilitator and explaining.

\section{Lokasi dan Waktu Penelitian}

\section{Lokasi penelitian}

Penelitian melakukan penelitian tindakan kelas ini di kelas IV SD Swasta Budi Murni 2. Waktu penelitian dilaksanakan pada bulan Maret 2019. Penelitian dilakukan pada Semester Genap tahun pembelajaran 2018/2019 sebanyak dua siklus. Adapun waktu penelitian yang akan dilaksanakan adalah sebagai berikut:

\section{Waktu Penelitian}

Penelitian ini dilaksanakan pada semester genap tahun pembelajaran 2018/2019.

\section{Subjek dan Objek Penelitian}

\section{Subjek Penelitian}

Subjek dalam penelitian tindakan kelas ini adalah siswa kelas IV SD Swasta Budi Murni 2 Tahun Pembelajaran 2018/2019 yang berjumlah 48 orang terdiri dari 19 siswa laki-laki dan 29 siswi perempuan.

\section{Objek Penelitian}

Objek penelitian ini adalah hasil belajar tema 8 daerah tempat tinggalku siswa kelas IV SD Swasta Budi Murni 2 penerapan model pembelajaran student facilitator and explaining untuk meningkatkan hasil belajar siswa pada tema 8 daerah tempat tinggalku.

\section{Jenis dan Sumber Data}

\section{Jenis Data}

jenis data yang digunakan peneliti pada penelitian ini adalah jenis data kualitatif dan kuantitatif.

a. Data Kualitatif

Data kualitatif dari penelitian ini adalah data yang diisi oleh observer dengan berdasarkan pengamatan dilapangan tentang sikap dan ketrampilan siswa maupun guru.

b. Data Kuantitatif

Data kuantitatif dari penelitian ini adalah suatu proses mengetahui pengetahuan siswa dengan menggunakan data berupa angka sebagai alat menemukan keterangan mengenai kemampuan siswa dalam proses pembelajaran. Yang termasuk kedalam data kuantitatif adalah hasil belajar siswa. 


\section{Sumber Data}

Sumber data merupakan subjek dari mana data dapat diperoleh. Sumber data penelitian ini adalah sumber data primer dan sumber data sekunder. Sumber data primer yaitu informan (orang) yang dapat memberikan informasi tentang data penelitian. Informan dalam penelitian ini siswa kelas IV SD Swasta Budi Murni 2 yang terdiri dari 48 orang siswa. Hal ini menjadi pertimbangan untuk mengetahui sejauh mana keberhasilan siswa dalam pembelajaran yang diberikan tindakan dengan diterapkannya penggunaan Model pembelajaran Student Facilitator and Explaining pada tema 8 daerah tempat tinggalku.

Sumber data sekunder yaitu sumber yang tidak langsung memberikan data kepada pengumpul data. Sumber data tersebut adalah data hasil belajar yang dikumpilkan oleh orang lain yaitu data pendukung dalam penelitian ini Kepala Sekolah SD Swasta Budi Murni 2. Jenis data sekunder yang digunakan dalam penelitian ini adalah aktivitas, tempat atau lokasi, dan dokumentasi atau arsip siswa.

\section{Teknik dan Alat Pengumpulan Data}

Teknik pengumpulan data yang digunakan dalam penelitian ini adalah menggunakan analisis data kuantitatif dan analisis data kualitatif yang dilakukan setiap kali setelah pemberian suatu tindakan pembelajaran pada setiap siklus.

Untuk mengetahui hasil belajar yang dicapai oleh siswa dengan menggunakan model pembelajaran student facilitator and explaining, alat pengumpulan data yang digunakan dalam penelitian ini adalah dengan menggunakan teknik observasi dan tes.

\section{Observasi}

Observasi dilakukan untuk mengamati kegiatan di kelas selama kegiatan pembelajaran berlangsung. Kegiatan yang diamati meliputi aktivitas guru dan aktivitas siswa dalam pembelajaran

\section{Tes}

Tes adalah alat yang digunakan untuk mengukur perkembangan atau kemajuan belajar peserta didik dengan cara pemberian soal. Soal-soal yang diberikan sebanyak 29 soal mengenai tema 8 daerah tempat tinggalku dan subtema 3 bangga terhadap daerah tempat tinggalku dalam bentuk pilihan berganda, dimana siswa memilih salah satu jawaban yang benar. Tes yang diberikan sesuai dengan tujuan pembelajaran yang hendak dicapai dan instrument dalam penelitian ini adalah evaluasi belajar dan aspek kongnitifnya 
melibatkan dari berbagai macam aspek yakni pengetahuan (C1), pemahaman (C2), aplikasi (C3), dan analisis (C4)

\section{Dokumentasi}

Dokumentasi dilakukan untuk mendapatkan sumber informasi dengan bukti yang akurat seperti hasil nilai prates, siklus I, siklus II, observasi aktivitas guru, observasi aktivitas siswa dan gedung sekolah SD Swasta Budi Murni 2.

\subsection{Uji Instrumen Data}

\section{Validitas}

Validitas adalah ketepatan alat penilaian terhadap konsep yang dinilai sehingga benar-benar menilai apa yang seharusnya dinilai. Validitas tiap butir soal atau validitas item digunakan untuk mengetahui tingkat kevalitan masing-masing tiap butir soal sehingga dapat ditentukan tiap butir soal yang gagal dan yang diterima.

Agar instrumen yang dibuat oleh peneliti dapat dikatakan valid maka dilakukan uji validitas. Validitas dalam penelitian ini dilakukan dengan diuji dan diperiksa validnya, sehingga data tersebut dapat dipertanggungjawabkan. Perhitungan uji validitas ini menggunakan bantuan SPSS dan Microsoft exel. Uji validitas pada penelitian ini menggunakan product moment dengan mengkorelasikan antara skor yang didapat siswa pada suatu butir soal dengan skor total yang didapat.

Adapun cara yang digunakan untuk mengukur validitas instrument sebagai berikut:

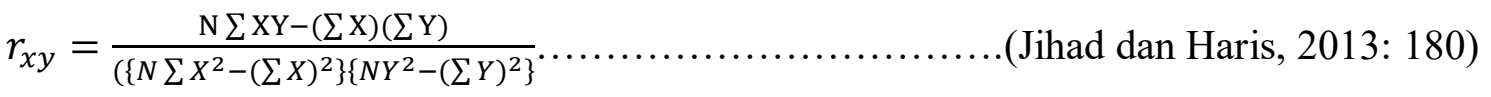

Keterangan :

$r_{x y}=$ Koefisien korelasi antara variable $\mathrm{X}$ dan $\mathrm{Y}$

$\mathrm{N} \quad=$ Banyaknya peserta tes

$\mathrm{X}=$ Nilai hasil uji coba

$\mathrm{Y} \quad=$ Nilai rata-rata siswa

Keputusan pengujian validitas instrument adalah:

a. Item pernyataan dikatakan valid apabila $\boldsymbol{r}_{\text {hitung }}>\boldsymbol{r}_{\text {tabel }}$ pada taraf signifikasi $0,5 \%$

b. Item pernyataan dikatakan tidak valid apabila $\boldsymbol{r}_{h i t u n g}<\boldsymbol{r}_{\text {tabel }}$ pada taraf signifikasi $0,5 \%$

Nilai $\boldsymbol{r}_{x y}$ yang diperoleh setelah dihitungmenggunakan rumus validitas adalah 0,718 jika dibandingkan dengan nilai $\boldsymbol{r}_{\text {tabel }}$ yaitu sebesar 0,388 , maka diperoleh $\boldsymbol{r}_{x y}$ lebih 
besar dari $\boldsymbol{r}_{\text {tabel }}$ yaitu $0,718>0,388$ maka untuk soal instrument soal nomor 1 dinyatakan valid.

Suatu instrument dikatakan valid jika $\boldsymbol{r}_{\text {hitung }}>\boldsymbol{r}_{\text {tabel }}$, pada uji validitas ini maka $\boldsymbol{r}_{\text {tabel }}$ sebesar 0,388 dengan taraf signifikan 5\% dan jumlah responden sebanyak 26 orang.

\section{Realibilitas}

Setelah diketahui dari instrument soal maka dilakukan kembali dengan realibilitas soal merupakan ukuran yang menyatakan kesenjangan kekonsistenan suatu soal tes. Untuk mengukur tingkat kesenjangan soal ini digunakan perbandingan K-R.20 rumus yang digunakan dinyatakan dengan:

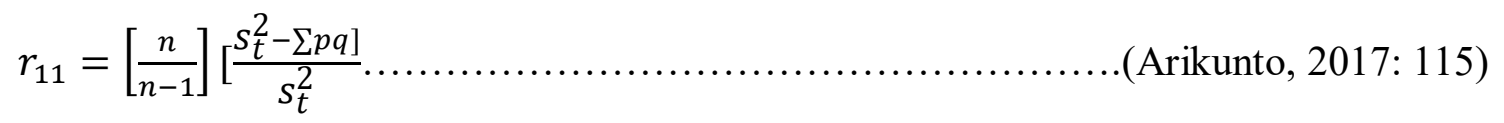

Keterangan :

$r_{11}=$ Reliabilitas tes secara keseluruhan

$\mathrm{N} \quad=$ Banyaknya butir soal

$\mathrm{P} \quad$ = proporsi subjek yang menjawab item dengan benar

$\mathrm{q}=$ proporsi subjek yang menjawab item dengan salah $(\mathrm{q}=1-\mathrm{p})$

$\sum \mathrm{Pq}=$ jumlah hasil perkalian $\mathrm{p}$ dan $\mathrm{q}$

$s_{t}^{2} \quad=$ standar deviasi dari tes

Interpretasi terhadap nilai koefisien $r_{11}$ digunakan kriteria sebagai berikut:

$r_{11} \leq 0,20 \quad:$ Reliabilitas sangat rendah

$0,20<r_{11} 0,40 \quad:$ Reliabilitas rendah

$0,40<r_{11} 0,70 \quad$ : Reliabilitas sedang

$0,70<r_{11} 0,90 \quad$ : Reliabilitas tinggi

$0,90<r_{11} 1,00 \quad$ : Reliabilitas sangat tinggi

Dari 50 soal yang telah diujicobakan kepada siswa terdapat 29 soal yang valid sehingga dapat dihitung reliabilitas tes dengan menggunakan rumus KR-20 yaitu :

$r_{11}=\left[\frac{n}{n-1}\right]\left[\frac{\left.s_{t}^{2}-\sum p q\right]}{s_{t}^{2}}\right.$

\section{Analisis Data}

Menurut sugiyono (2017: 335) mengatakan bahwa "analisis data adalah proses mencari dan menyusun secara sistematis data diperoleh dari hasil wawancara, catatan lapangan, dan dokumentasi, dengan cara mengorganisasikan data kedalam kategori menjabrkan kedalam unit-unit melakukan sintesa, menyusun kedalam pola, memilih mana 
yang penting dan yang akan dipelajari, dan membuat kesimpulan sehingga mudah dipahami oleh diri sendiri maupun orang lain". Analisis data yang digunakan dalam penelitian ini adalah kualitatif dan kuantitatif. Kualitatif berupa pengisian lembar observsi terhadap pelaksanaan pelajaran yang akan dilakukan pleh guru. Kuantitatif yaitu tes awal dan tes akhir dalam proses pembelajaran pada masing-masing siklus.

\section{Hasil Pelaksanaan Pembelajaran}

Untuk mengetahui berhasil atau tidaknya yang dilakukan dan untuk mengetahui pelaksanaan pembelajaran, analisis data yang dapat dilakukan yaitu sebagai berikut:

a. Penilaian Aktivitas Guru

Untuk mengetahui keefektifan akifitas guru dalam pelaksanaan pembelajaran, dengan rumus:

Nilai $=\frac{\text { Total skor }(\text { perolehan })}{\text { skor } \text { maksimal }} \times 100 \%$

..(Tampubolon, 2016: 166)

Tabel 3.6 Penilain Aktifitas Guru

\begin{tabular}{|c|c|c|}
\hline Interval nilai & Ketegori & Makna \\
\hline $81-100$ & $\mathrm{~A}$ & Sangat baik \\
\hline $61-80$ & $\mathrm{~B}$ & Baik \\
\hline $41-60$ & $\mathrm{C}$ & Cukup baik \\
\hline $21-40$ & $\mathrm{D}$ & Kurang baik \\
\hline $0-20$ & $\mathrm{E}$ & Sangat kurang \\
\hline
\end{tabular}

Sumber: Tampubolon, (2016: 166)

b. Penilaian Aktivitas Siswa

Untuk mengetahui keefektifan aktivitas siswa dalam pelaksanaan pembelajaran, digunakan rumus:

Nilai $=\frac{\text { Total } \text { skor }(\text { perolehan })}{\text { skor } \text { maksimum }} \times 100$ (Jihad dan Haris, 2018: 130)

Tabel 3.7 Penilain Aktifitas Siswa

\begin{tabular}{|c|c|}
\hline Nilai & Kriteria \\
\hline $90-100$ & Sangat baik \\
\hline $70-89$ & Baik \\
\hline
\end{tabular}




\begin{tabular}{|c|c|}
\hline $50-69$ & Cukup \\
\hline $30-49$ & Kurang \\
\hline $10-29$ & Sangat kurang \\
\hline
\end{tabular}

Sumber: Jihad dan Haris, (2018: 130)

\subsubsection{Hasil Belajar}

a. Mencari nilai rata-rata

Dalam belajar, kita harus mengetahui peningkatan hasil belajar siswa untuk itu kita perlu mencari nilai rata-rata yang didapatkan siswa, maka digunakan rumus sebagai berikut:

$\mathrm{X}=\frac{\sum x}{\sum x}$ (Aqib, dkk, 2016: 40)

Keterangan $\mathrm{x}$ : nilai rata-rata

$\sum X:$ jumlah semua nilai siswa

$\sum \mathrm{N}$ : jumlah siswa

b. Ketuntasan belajar siswa

Setiap siswa dikatakan tuntas belajarnya jika nilai yang diperoleh siswa telah mencapai $\mathrm{KKM}=75$, sesuai dengan yang ditetapkan disekolah. Untuk menetukan ketuntasan belajar siswa dapat dihitung digunakan rumus sebagai berikut:

$\mathrm{KB}=\frac{T}{T t} \times 100 \%$ (Trianto, 2016: 241)

Keterangan:

$\mathrm{KB}=$ ketuntasan belajar

$\mathrm{T}=$ jumlah skor yang diperoleh siswa

$\mathrm{Tt} \quad=$ jumlah skor total

c. Ketuntasan Klasikal

$\mathrm{P}=\frac{\sum \text { siswa yang tuntas belajar }}{\sum \text { siswa }} \times 100 \%$ ..(Aqib, dkk, 2016: 40)

Tabel 3.8 Kriteria Tingkat Keberhasilan Belajar Siswa Dalam \%

\begin{tabular}{|c|c|}
\hline Tingkat keberhasilan siswa $(\%)$ & Rentangan kategori \\
\hline$>80 \%$ & Sangat tinggi \\
\hline $60-79 \%$ & Tinggi \\
\hline $40-59 \%$ & Sedang \\
\hline
\end{tabular}




\begin{tabular}{|c|c|}
\hline $20-39 \%$ & Rendah \\
\hline$<20 \%$ & Sangat rendah \\
\hline
\end{tabular}

\section{Indikator Kinerja Penelitian}

Indikator kinerja adalah kriteria yang digunakan untuk melihat tingkat keberhasilan siswa dalam proses kegiatan penelitian yang dilakukan peneliti, melalui penggunaan model pembelajaran yang telah diterapkan. Penggunaan model pembelajaran student facilitator and explaining pada tema daerah tempat tinggalku dengan subtema bangga terhadap daerah tempat tinggalku di kelas IV SD Swasta Budi Murni 2 dengan kriteria sebagai berikut:

1) Indikator keberhasilan kualitas proses pembelajaran minimal "baik" ( indikator ini untuk tujuan umum dalam penelitian).

2) Indikator keberhasilan hasil belajar siswa secara klasikal minimal $85 \%$ dari jumlah siswa yang mencapai KKM yang ditetapkan.

\section{Desain Penelitian}

Rancangan dalam penelitian ini adalah Penelitian Tindakan Kelas. Secara garis besar terdapat empat tahapan yang dilalui dalam melaksanakan penelitian tindakan kelas, yaitu perencanaan, tindakan, observasi, dan refleksi.

\section{Prosedur Penelitian}

Prosedur dalam penelitian ini dilakukan dengan 2 siklus, yaitu siklus I dan siklus II. Langkah penelitian tindakan kelas ini dilakukan melalui 4 tahap sebagai berikut: (1) perencanaan, (2) tindakan, (3) observasi, (4) refleksi.

\section{Prasiklus}

Prasiklus merupakan refleksi awal sebelum penelitian tindakan siklus dilakukan untuk mengetahui hasil belajar siswa sebelum masuk keadaan siklus I yang menerapkan model pembelajaran student facilitator and explaining. Guru memberikan tes awal berupa soal pilihan berganda. adapun langkah-langkah yang dilakukan pada tahap ini sebagai berikut:

\section{Siklus I}

\section{Perencanan}

Kegiatan yang dilakukan pada tahap ini adalah peneliti mengadakan pertemuan degan guru kelas untuk membahas teknis pelaksanaan penelitian tindakan kelas ini. Selanjutnya peneliti mempersiapkan diantaranya: 
a. Menyususn Rencana Pelaksanaan Pembelajaran (RPP)

b. Menyediakan media pembelajaran yang sesuai dengan materi pelajaran dan yang dibutuhkan selama proses belajar mengajar berlangsung

c. Mempersiapkan instrumen lembar observasi hasil belajar siswa dan lembar observasi kemampuaan guru saat mengajar

d. Menyusun lembar kerja siswa (LKS) beserta pertanyaan yang akan diajukan guru kepada siswa

e. Menyusun soal postes beserta kunci jawaban untuk mengukur keberhasilan siswa pada tema 8 daerah tempat tinggalku dan sub tema 3 bangga terhadap tempat tinggalku pada pembelajaran 4

\section{Pelaksanaan Tindakan}

Kegiatan yang dilakukan pada tahap ini antara lain:

a. Guru membuka kegiatan pembelajaran dan mengajak siswa berdoa bersama.

b. Guru melakukan apersepsi dan motivasi

c. Guru menyampaikan tujuan pembelajaran dan langkah-langkah pembelajaran serta kompetensi yang ingin dicapai dalam pembelajaran

d. Guru menjelaskan materi pembelajaran kepada siswa tentang daerah tempat tinggalku

e. Untuk memantapkan penguasaan, Guru memberi kesempatan kepada masing-masing kelompok untuk menjelaskan kembali materi yang telah dijelaskan oleh guru misalnya daerah tempat tinggalku dengan bimbingan guru

f. Guru dan peserta didik memberi penghargaan berupa pujian bagi temanya yang telah mau maju kedepan menjelaskan materi daerah tempat tinggalku, kemudian guru menyimpulkan penjelasan dari masing-masing yang telah maju kedepan kelas.

g. Siswa diminta mengerjakan LKS yang dibagikan guru

h. Guru dan siswa menyimpulkan materi pembelajaran yang sudah dipelajari

i. Guru menutup pelajaran dengan cara memotivasi mereka agar lebih rajin belajar dirumah.

\section{Observasi/Pengamatan}

Pada tahap ini peneliti mengamati pelaksanaan yang sedang berlangsung dengan menggunakan lembar observasi yang telah dijadikan. Kegiatan observasi dilakukan selama pembelajaran berlangsung dibantu oleh guru kelas menyangkut aktivitas belajar siswa dalam mengikuti pelajaran dan memberi tanda ceklis pada lembar observasi. Peneliti 
mengamati aktivitas siswa selama mengikuti pelajaran dengan menggunakan model pembelajaran student facilitator and explaining. Observasi ini bertujuan untuk melihat kesesuain tindakan dengan rencana yang telah disusun guna mengetahui sejauh mana pelaksanaan tindakan dapat menghasilkan perubahan sesuai dengan yang dikehendaki.

\section{$4 \quad$ Refleksi}

Kegiatan refleksi dilakukan berdasarkan hasil yang telah diperoleh dari tahap tindakan dan observasi yang telah dikumpulkan, lau dianalisis untuk melihat kesesuaian yang dicapai dengan yang diinginkan dalam pembelajaran. Sehingga dapat diketahui kekurangan maupun kebaikan dari tindakan yang telah dilaksanakan. Hasil refleksi ini kemudian digunakan sebagai dasar untuk tahap perencanaan pada siklus berikutnya. Apabila pada siklus I hasil belajar siswa belum memuaskan, maka peneliti merencanakan tidakan pada siklus II. Kemudian hasil refleksi siklus I digunakan sebagai dasar untuk tahap perencanaan terhadap siklus II.

\section{Siklus II}

Tahap perencanaan pada siklus II dilaksanakan sama halnya dengan siklus I yang mencakup perencanaan, pelaksanaan tindakan, pengamatan, refleksi, dan perbaikan rencana. Pada siklus II dilakukan tahapan-tahapan seperti pada siklus pertama, tetapi didahului dengan perencanaan ulang berdasarkan hasil-hasil yang diperoleh pada siklus pertama, sehingga kelemahan-kelemahan yang terjadi pada siklus pertama tidak terjadi pada siklus kedua.

\section{Perencanaan}

Kegiatan yang dilakukan pada tahap ini anatara lain:

a. Menyususn Rencana Pelaksanaan Pembelajaran (RPP)

b. Menyediakan media pembelajaran yang sesuai dengan materi pelajaran dan yang dibutuhkan selama proses belajar mengajar berlangsung

c. Mempersiapkan instrumen lembar observasi hasil belajar siswa dan lembar observasi kemampuaan guru saat mengajar

d. Menyusun lembar kerja siswa (LKS) beserta pertanyaan yang akan diajukan guru kepada siswa

e. Menyusun soal postes beserta kunci jawaban untuk mengukur keberhasilan siswa pada tema 8 daerah tempat tinggalku dan sub tema 3 bangga terhadap tempat tinggalku pada pembelajaran 4

\section{Pelaksanaan Tindakan}


Adapun pelaksanaan tindakan pada siklus II ini adalh sebagai berikut:

a. Guru membuka kegiatan pembelajaran dan mengajak siswa berdoa bersama.

b. Guru melakukan apersepsi dan motivasi

c. Guru menyampaikan tujuan pembelajaran dan langkah-langkah pembelajaran serta kompetensi yang ingin dicapai dalam pembelajaran

d. Guru menjelaskan materi pembelajaran kepada siswa tentang daerah tempat tinggalku

e. Untuk memantapkan penguasaan, Guru memberi kesempatan kepada masing-masing kelompok untuk menjelaskan kembali materi yang telah dijelaskan oleh guru misalnya daerah tempat tinggalku dengan bimbingan guru

f. Guru dan peserta didik memberi penghargaan berupa pujian bagi temanya yang telah mau maju kedepan menjelaskan materi daerah tempat tinggalku, kemudian guru menyimpulkan penjelasan dari masing-masing yang telah maju kedepan kelas.

g. Siswa diminta mengerjakan LKS yang dibagikan guru

h. Guru dan siswa menyimpulkan materi pembelajaran yang sudah dipelajari

i. Guru menutup pelajaran dengan cara memotivasi mereka agar lebih rajin belajar dirumah.

\section{Observasi/Pengamatan}

Seperti pada siklus I. pengamatan atau observasi dilakukan untuk melihat perubahan yang terjadi pada siswa selama belajar. Dan pada siklus II dilakukan untuk melihat kekurangan yang terjadi pada saat pembelajaran berlangsung dengan menggunakan model pembelajaran student facilitator and explaining.

\section{Refleksi}

Refleksi dilakukan setelah selesai pembelajaran dan evaluasi pada siklus II. Tahap ini mengemukakan kembali secara rinci segala sesuatu yang terjadi dikelas selama pertemuan siklus II. Jika pada tahapan siklus masih ditemukan banyak siswa yang belum mampu maka dilaksanakan siklus selanjutnya, namun jika telah memenuhi tujuan yang diinginkan maka tidak perlu dilakukan tindakan pada siklus selanjutnya, dengan kata lain pembelajaran dianggap selesai.

\section{HASIL PENELITIAN DAN PEMBAHASAN}

\section{Pembahasan Hasil Temuan}

Hasil penelitian yang dilaksanakan di SD Swasta Budi Murni 2 menunjukan bahwa dengan menggunakan model pembelajaran student facilitator and explaining dapat 
meningkatkan hasil belajar di kelas IV SD. Berdasarkan hasil penelitian dari 48 siswa, yang tuntas pada prates sebanyak 14 orang siswa $(29,17 \%)$ dan yang tidak tuntas sebanyak 34 siswa $(70,83 \%)$ dengan nilai rata-rata 67,47. Pada siklus I siswa yang tuntas sebanyak 23 siswa $(47,91 \%)$ dan yang tidak tuntas sebanyak 25 siswa $(52,083 \%)$ dengan nilai ratarata 73,44 . Selanjutnya karena hasil yang diperoleh belum mencapai indikator keberhasilan maka dilakukan siklus II. Pada siklus II diperoleh siswa yang tuntas sebanyak 46 siswa $(95,83 \%)$ dan yang termasuk ke dalam kategori tidak tuntas sebanyak 2 siswa $(4,17 \%)$ dengan nilai rata-rata 95,45 .

Berdasarkan hal tersebut, penggunaan model pembelajaran student facilitator and explaining dapat meningkat hasil belajar siswa pada tema 8 daerah tempat tinggalku dan sub tema 3 bangga terhadap daerah tempat tinggalku pada pembelajaran ke 4 di kelas IV SD. Peningkatan hasil belajar siswa dapat dilihat ketuntasan hasil belajar siswa secara klasikal dapat digambarkan pada grafik dibawah ini:

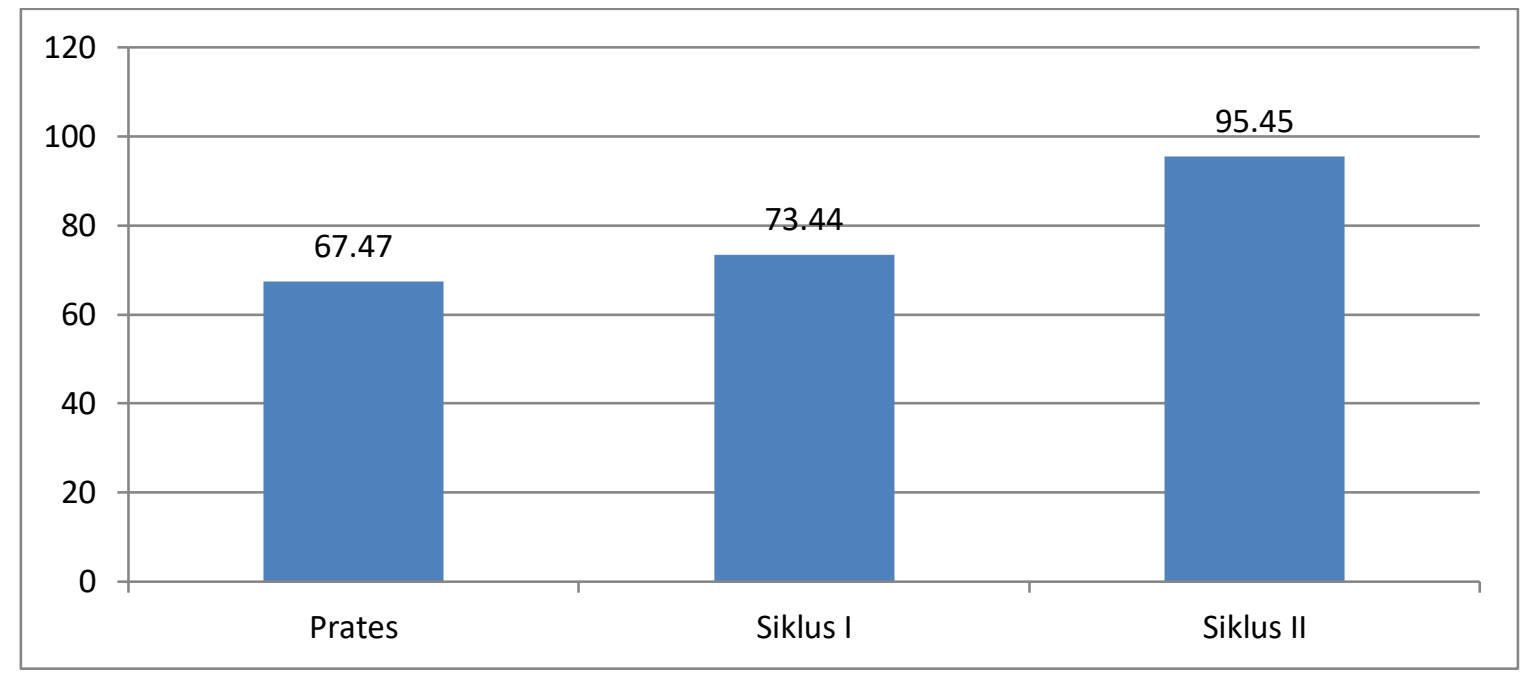

Gambar Diagram Ketuntasan Hasil Belajar Siswa pada Klasikal

Persentasi peningkatan ketuntasan hasil belajar siswa dapat digambarkan pada grafik dibawah ini: 


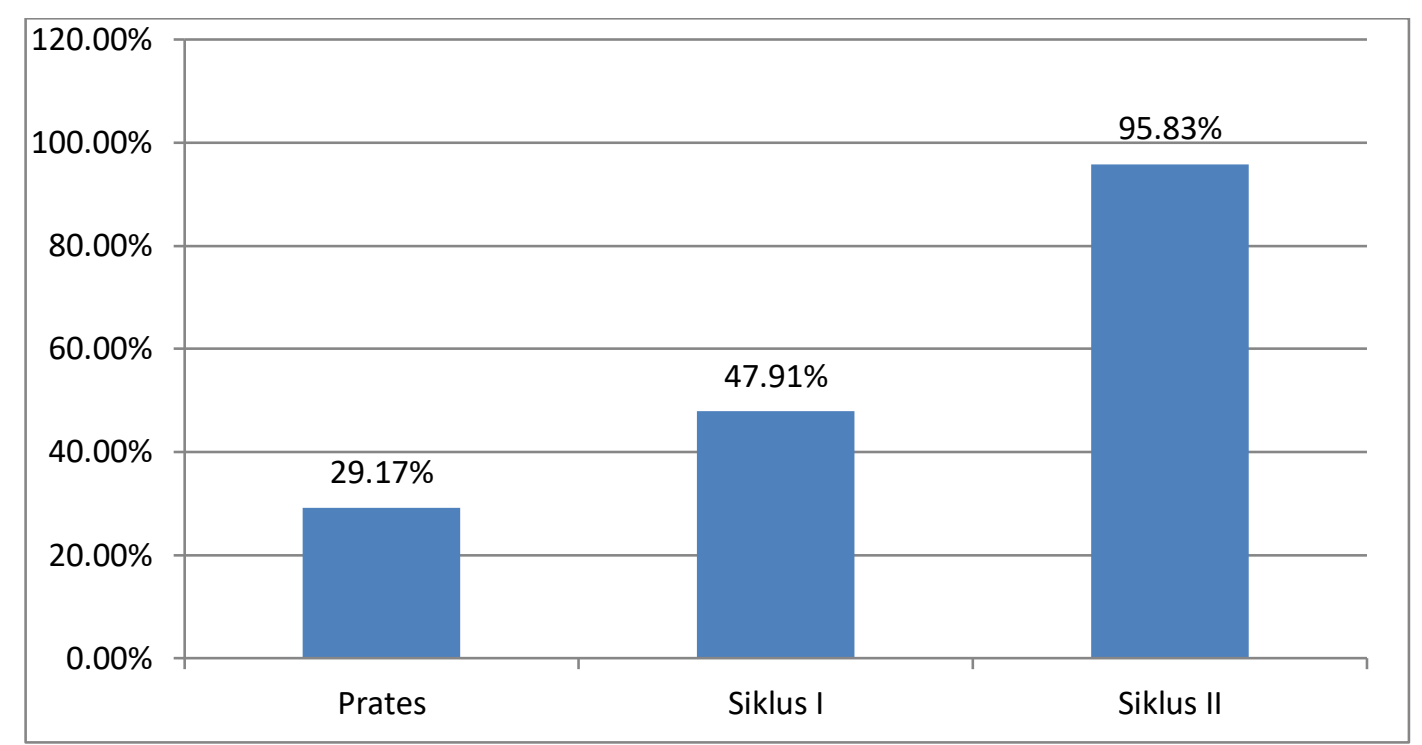

Gambar Diagram Persentasi Peningkatan Ketuntasan Hasil Belajar Siswa antar Siklus

Peningkatan hasil belajar siswa dapat juga dilihat dari rata-rata nilai yang diperoleh dari prates, siklus I, dan siklus II, peningkatan hasil belajar siswa di gambarkan pada grafik berikut ini:

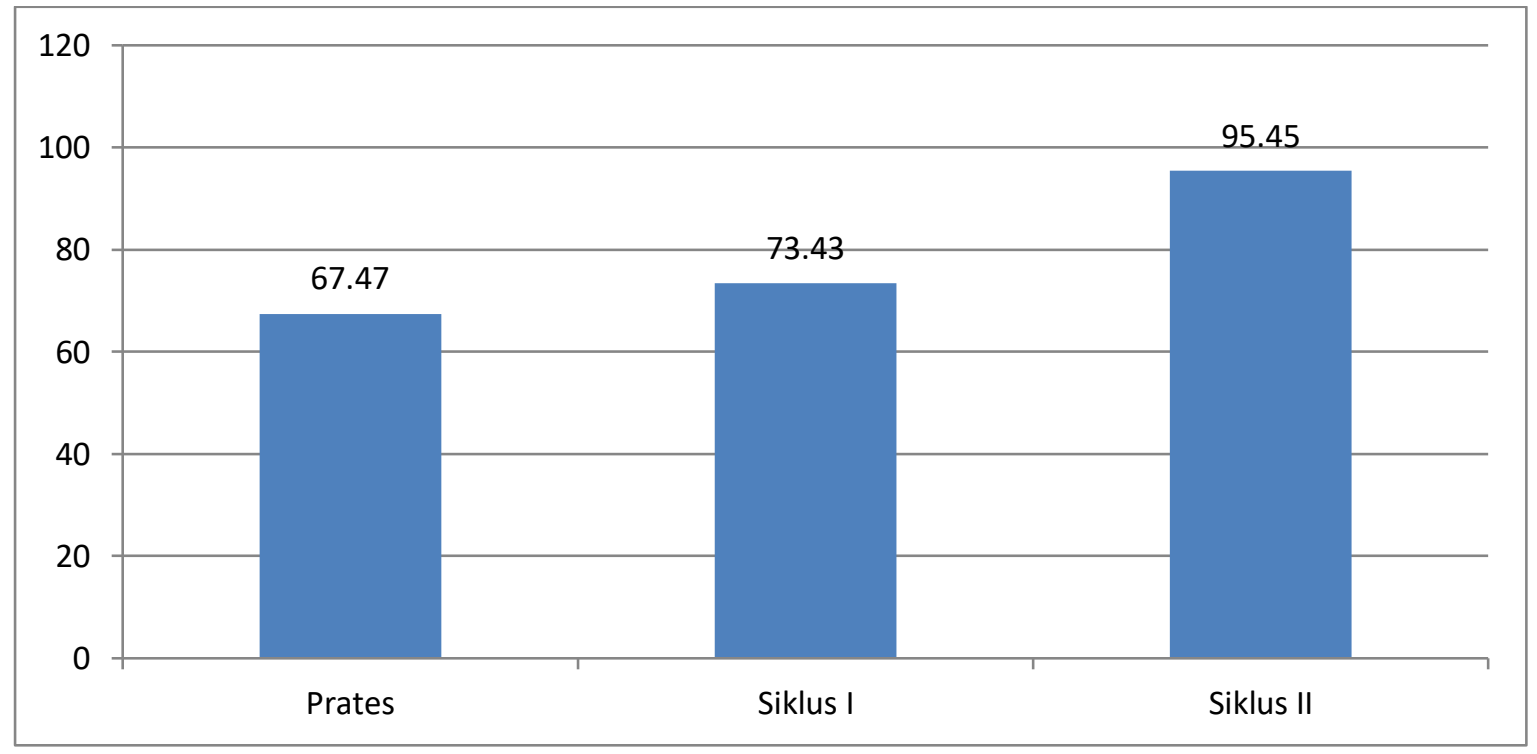

\section{Gambar 4.12 Diagram Peningkatan nilai Rata-rata Siswa}

Berdasarkan grafik di atas, dapat dilihat bahwa terdapat peningkatan hasil belajar. Jadi dapat disimpulkan bahwa melalui hasil temuan, telah diperoleh jawaban terhadap hipotesis tindakan yang telah dikemukakan sebelumnya, bahwa dengan menggunakan model pembelajaran student facilitator and explaning dapat meningkatkan hasil belajar siswa kelas IV SD Swasta Budi Murni 2. 


\section{PENUTUP}

\section{Simpulan}

Berdasarkan hasil penelitian dan pembahasan yang telah diuraikan pada bab 4, dengan menerapkan model pembelajaran student facilitator and explaining diperoleh beberapa kesimpulan sebagai berikut:

1. Dengan menerapkan model pembelajaran student facilitator and explaining pada tema 8 daerah tempat tinggalku dan subtema 3 bangga terhadap daerah tempat tinggalku pada pembelajaran ke 4, dapat meningkatkan hasil belajar siswa dan sudah memenuhi kriteria ketuntasan minimal (KKM) yang ditetapkan oleh sekolah yaitu 75. Hal ini dapat dilihat dari persentasi ketuntasan belajar secara klasikal dan nilai rata-rata siswa yaitu, pada prates siswa yang tuntas sebanyak 14 orang siswa $(29,17 \%)$ dan siswa yang tidak tuntas 34 orang siswa $(70,83 \%)$ dengan nilai rata-rata 67,47 , pada siklus I siswa yang tuntas sebanyak 23 orang siswa $(47,91 \%)$ dan siswa yang tidak tuntas 25 orang siswa $(52,08 \%)$ dengan nilai rata-rata 73,43 dan pada siklus II siswa yang tuntas sebanyak 46 orang siswa $(95,83 \%)$ dan siswa yang tidak tuntas 2 orang $(4,17 \%)$ dengan nilai rata-rata 95,45.

2. Aktivitas guru dalam pembelajaran pada tema 8 daerah tempat tinggalku dan subtema 3 bangga terhadap daerah tempat tinggalku pembelajaran ke 4 dengan menerapkan model pembelajaran student facilitator and explaining mengalami peningkatan. Hal ini dapat dilihat berdasarkan rata-rata persentasi skor aktivitas guru pada siklus I sebesar 70,91\% dengan kategori baik dan pada siklus II sebesar $86 \%$ dalam kategori baik dan pada setiap siklus mengalami peningkatan dan telah memenuhi indikator keberhasilan.

3. Aktivitas siswa dalam pembelajaran pada tema 8 daerah tempat tinggalku dan subtema 3 bangga terhadap daerah tempat tinggalku pembelajaran ke 4 dengan menerapkan model pembelajaran student facilitator and explaining mengalami peningkatan. Hal ini dapat dilihat berdasarkan rata-rata persentasi skor aktivitas siswa pada siklus I sebesar 68 dengan kategori cukup, dan pada siklus II sebesar 88 dengan kategori baik. pada proses penelitian ini pada tahap observasi pada setiap siklus mengalami peningkatan. 


\section{Saran}

Berdasarkan hasil penelitian tindakan kelas yang diperoleh dari SD Swasta Budi Murni 2, maka peneliti menyarankan beberapa hal yaitu sebagai berikut:

1. Bagi guru, diharapkan memahami karakteristik siswa, dan mulai menggunakan model pembelajaran yang bervariasi seperti model pembelajaran student facilitator and explaining guru hendaknya mengetahui kebutuhan-kebutuhan siswa dalam belajar dan dapat mengaitkan materi pelajaran dengan kehidupan sehari-hari sehingga pembelajaran yang dilakukan dapat lebih bermakna, dan dapat meningkatkan hasil belajar siswa.

2. Bagi sekolah, diharapkan mendukung perkembangan pembelajaran yang akan dilakukan guru dalam rangka meningkatkan kualitas pembelajaran, sehingga hasil belajar siswa dapat meningkat.

3. Bagi peneliti lain, diharapkan untuk lebih banyak lagi mencari informasi mengenai model pembelajaran yang tepat digunakan dalam kegiatan belajar mengajar sehingga suasana pembelajaran di kelas dapat berjalan dengan lancar dan dapat mencapai tujuan pembelajaran serta meningkatkan kualitas pendidikan.

\section{DAFTAR PUSTAKA}

Aqib, Zainal, dkk. 2016.PenelitianTindakanKelas. Bandung: YramaWidya.

Arikunto, Suharsimi, dkk. 2017. PenelitianTindakanKelas. Jakarta: BumiAksara.

Eprianti, Sari Indah. 2017: Meningkatkan Hasil Belajar IPA Siswa Dengan Menggunakan Model Pembelajaran Kooperatif TipeThe Power Of Two Di Kelas IV SDN No 054878 Lau Mulgap Kecamatan Selesai Kabupaten Langkat Tahun Pembelajaran 2016/2017: Perpusatakaan UNIKA, Medan.

Fathurrohman, Muhammad. 2015. Model-model Pembelajaran Inovatif. Yogyakarta :ArRuzz Media.

Hanum, Meyva. 2018: Meningkatkan Hasil Belajar Siswa Pada Mata Pelajaran IPA Dengan Menggunakan Model Pembelajaran Student Facilitator And Explaining di Kelas IV SDN 055993 Perdamaian Tahun Pembelajaran 2017/2018: PerpustakaanUnimed, Medan.

Huda, Miftahul. 2014. Model-model PengajarandanPembelajaran. Yogyakarta: PustakaBelajar.

Jendri, Ngodu. 2014. "Penerapan model pembelajaran Student Facilitator and Explaining dalammeningkatjanhasilbelajar PKN di kelas IV SDN Lobong'. JurnalFakultasIlmuPendidikan (JFIP) 2(4) 
Jihad, Haris. 2013. EvaluasiPembelajaran. Yogyakarta: Multi Pressindo

Khairani, Makmun. 2017. PsikologiBelajar. Yogyakarta: AswajaPressindo.

Kurniasih, I. \&Sani, B. 2015.Model Pembelajaran: Kata Pena.

Kurniawan, Deni. 2014. PembelajaranTerpaduTematik. Bandung: Alfabeta.

Kustini, Wiwik. 2016. MelaluiMetodeStudent Facilitator And Explaining (SFAE) MeningkatkanPrestasiBelajar MATEMATIKA MateriJaringJaringKubusdanBalokKelas IV-B Semester II Tahun 2014/2015 Di SD Negeri 2 SurodakanKecamatanTrenggalekKabupaten JurnalPendidikanProfesional 5(2): 207-217.

Maselleng, Jumatia. dan Mawa'Ratu Samuel. 2015. Penerapan Model Student Facilitator And Explaining UntukMeningkatkanHasilBelajar PKN SiswaKelas IV SDN 5 TallunglipuKabupatenToraja Utara. Jurnal Kip 4(2): 879-886.

Mulyasa. 2017. PengembanganImplementasiKurikulum 2013.Bandung: RemajaRosdakarya

Pidarta, Made. 2014. LandasanKependidikan. Jakarta: RinekaCipta

Pulungan, Istirani. 2017. EnsiklopediPendidikan. Medan: Media Persada.

Purwanto. 2017. EvaluasiHasilBelajar. Yogyakarta: PustakaPelajar.

Rusman. 2017. Belajar dan Pembelajaran. Jakarta: Kencana.

Sanjaya, Wina. 2016. KurikulumdanPembelajaran. Jakarta: KencanaPrenada Media Group.

Saragih, Ria. dkk. 2014: Meningkatkan Kemampuan Kongnitif Siswa Melalui Model Pembelajaran Student Facilitator and Explaining Pada Mata Pelajaran IPA Kelas IV SDN Sei Rotan Tahun Pembelajaran 2013/2014: PerpustakaanUnimed, Medan.

Slameto. 2017. Belajar Dan Factor-Faktor yang Mempengaruhi. Jakarta: RinekaCipta.

Subekti, Ari. 2016. Daerah TempatTinggalku. Jakarta: KementrianPendidikandanKebudayaan.

Suprijono, Agus. 2014. Cooperative Leraning. Yogyakarta: PustakaBelajar.

Susanto, Ahmad. 2017. TeoriBelajar\&Pembelajaran. Jakarta: Prenadamedia Group. 